\title{
Research of Highway on Water and Soil Conservation Facilities Acceptance Technology Assessment - Taking Fuzhou to Yinchuan Expressway of Jiujiang Changjiang River Highway Bridge as an Example
}

\author{
Lan Chen, Yi-feng Wang and Min Jiang
}

Changjiang River Scientific Research Institute of Changjiang Water Resources Commission, Huangpu street 23\#, Jiang'an strict, Wuhan, China

Keywords: Highway, Water and Soil Conservation Facilities Acceptance, Technical Evaluation.

\begin{abstract}
This paper Taking Fuzhou to Yinchuan expressway of Jiujiang Changjiang river highway bridge as an example, on the basis of the engineering general situation, the highway, water and soil conservation facilities acceptance technology assessment process was discussed, the content and methods of evaluation acceptance was made; the implementation of soil and water conservation facilities, project quality, monitoring and supervision, project investment, soil and water conservation effect and the evaluation opinions was evaluated. It was concluded that the project could be through the water and soil conservation facilities acceptance completion inspection and acceptance of conclusions; the experience of this kind of project of soil and water conservation facilities acceptance was summed up, which could provide reference for subsequent similar projects.
\end{abstract}

\section{Project Summary}

Fuzhou to Yinchuan expressway of Jiujiang Changjiang river highway bridge project is located in Jiangxi, Hubei province at the junction. The north shore was Hubei province Huangmei county Fenlu town, the south shore was Jiangxi province Jiujiang county Jiujiang development zone. The bridge was $89 \mathrm{~km}$ far from Huangshi Changjiang river bridge, and $10.8 \mathrm{~km}$ far from Jiujiang Changjiang river bridge. The engineering line starting point was Liujiadawu, through the Qili lake, across the Jingjiu railway, the Saicheng lake, jiujiang city development zone, jiujiang city, then crossed Jiurui road, Yong'an levee $(\mathrm{K} 17+886)$, the Changjiang $(\mathrm{K} 17+886 \sim \mathrm{K} 23+732)$, across hubei huangmei county Huangguang levee and Fenlu town, The finial point was at Xiaochi to huangmei highway(K33+ 92)

The total length of Jiujiang Changjiang river highway bridge was $25.19 \mathrm{~km}$, the road grade was highway and the design speed was $100 \mathrm{~km} / \mathrm{h}$. It was four lanes at the north of Fenlu cross, and six lanes at the Fenlu cross to Nanjiu exchange. The bridge structure design period was 100 years, the design load level was I , the width of subgrade and the deputy approach was 33.5 meters. The width of main span was 38.9 meters.

The construction included the Xiaochi service area at north coast, the Fenlu interchange, and two toll stations (the main line and ramp line each one). At the south coast there were Qilihu lake hinge, two Jiujiangxi interchange, three toll stations (the main line and two ramp lines), the management center and the maintenance work area. This project was jointly invested by the Jiangxi Provincial Department of transportation and the Hubei Provincial Department of transportation. The total investment was 4 billion 478 million yuan, of which civil investment of $\$ 3$ billion 300 million. The project started in September 2009, in October 2013 the main project and all ancillary works was completed, the total duration was 49 months.

\section{Soil and Water Loss in the Project Area}

The Hubei section of this project belonged to the key control area of soil and water loss in Hubei province. The Jiangxi section belonged to the key monitoring area of soil erosion in Jiangxi province. The project area belonged to the southern hilly area, and the soil loss tolerance was $500 \mathrm{t} /\left(\mathrm{km}^{2} \cdot \mathrm{a}\right)$, the main type of soil erosion was water erosion. The construction process of subgrade engineering 
area, bridge engineering area, the area and spoil earthwork excavation and filling are prone to serious soil erosion, these areas were the focus of acceptance. The earthwork excavation and filling of subgrade engineering area, bridge engineering area, the area of borrow and spoil was prone to serious soil erosion during construction, which were the focus of acceptance.

\section{Evaluation Program of Acceptance}

\section{Evaluation Content}

According to the approved soil and water conservation program and soil and water conservation acceptance rules[1-3], the evaluation group evaluated whether the soil and water conservation facilities met the design requirements and construction quality requirements, the use of funds and the prevention and control of soil erosion, from 3 aspects of soil and water conservation engineering measures, plant measures and financial economy.

\section{Evaluation Method[4,5]}

Through access to the main project design, construction, supervision, original records, soil and water conservation programs and other archival information, the unit project and sub project quality were inspected and evaluated, engineering construction management of the corresponding records, the implementation of investment were evaluated. The on-site survey, sampling investigation and review project completion were carried out. The construction quality, control effect and financial spending were made a comprehensive evaluation. Assessment team mainly adopted census with selective key inspection, and the method of combining the on the basis of the census, to focus on important unit engineering audit. Engineering measures were used by field measurements, plant measures were used by the method of vegetation samples to check.

\section{Water and Soil Conservation Facilities Acceptance Technology Assessment}

\section{Water and Soil Conservation Facilities Complete Situation Assessment}

Through land department approval documents and field measurements, the prevention and control of engineering construction of limitation of liability was $216.49 \mathrm{hm} 2$, including project responsibility scope for the prevention and control of these areas is $210.71 \mathrm{hm} 2$, affected zone including the resettlement area of $5.78 \mathrm{hm} 2$.

Engineering construction of soil and water conservation measures were synchronous implemented with the principal part of the project implementation. After the completion, the soil and water conservation measures were built. The engineering measures quantities included land leveling 90.13 $\mathrm{hm}^{2}$, overburden stripping $228700 \mathrm{~m}^{3}$, surface soil backfill $228700 \mathrm{~m}^{3}$, slope protection engineering $9.73 \mathrm{hm}^{2}$, drain pipe trench $25817 \mathrm{~m}, 8$ shafts, 229 collecting wells, 989 cubic meters stone, rain water storage project $3586 \mathrm{~m}^{2}$. The completed plant greening area was $81.19 \mathrm{hm}^{2}$, which included 19171 trees, 5978730 shrubs, turfing $18.13 \mathrm{hm}^{2}$, spray irrigation grass $1.51 \mathrm{hm}^{2}$, planting grass slope protection was $1.7 \mathrm{hm}^{2}$ 、Sow seed was $59.85 \mathrm{hm}^{2}$. Greening plant species included camphor, red flower in wood, goldenrain tree, cuckoo, heather, privet, green blue, lobular gardenia, cynodon dactylon, tall fescue, cuckoo, white clover etc. Temporary measures quantities included earth retaining wall $1741.4 \mathrm{~m}$, bagged soil drainage $1594.5 \mathrm{~m}$, film covering $3856 \mathrm{~m}^{2}$, non-woven film covering $2402 \mathrm{~m}^{2}$.

According to the monitoring and verification analysis, the reasonable arrangement of construction to the construction of the season, which avoided the rainy season. The use of advanced construction technology, strictly control the construction work belt width, effectively reduced the water loss and soil erosion in the construction process. Topsoil stripping and topsoil generation were piled at local, and temporary measures were taken, which protected the soil resources and prevented soil erosion. 


\section{Project Quality Evaluation of Soil and Water Conservation}

Soil and water conservation measures were incorporated in the construction units, design units, construction units, monitoring unit, supervision unit of the quality management system. The engineering measures were synchronous to the principal part of the project, which were divided into 66 units, 113 division engineering, 397 cells engineering. Assessment team inspected the records of project quality inspection and quality evaluation, checked soil and water conservation engineering measures for the prevention and control division. The earth, abandon slag field and other important units were mainly surveyed. The engineering measures of soil and water conservation had been built according to the principal part of the project and soil and water conservation. The quality inspection and test assessment procedures were in accordance with requirements, which were overall quality and met the acceptance criteria.

Construction schedule of plant measures were slightly behind the principal part of the project, which could be divided into 51 units, 73 division engineering, 162 cell engineering. The assessment team used field sampling investigation and statistics verification method, in the industry to verify virescence scope. The plant quality indicators of survival rate, survival rate, coverage, growth condition and appearance quality were in-situ investigated. The indications of grass coverage, tree crown density were measured by samples. The survival rate of trees was spot checked by point plots. The overall coverage rate, survival rate was obtained by using the weighted index and reference to related standards, which determined the quality level. Assessment team thought plant measures met the requirements of specification, and the quality was qualified.

\section{Monitoring and Supervision Evaluation of Water and Soil Conservation}

The soil and water conservation monitoring time of the project was from July 2012 to December 2014. The projected were constructed nearly three years prior to the monitoring unit. Soil and water loss situation prior to the construction of the project couldn't be reflected. The monitoring unit should carry out the monitoring work before construction in the similar projects in the future.

Soil and water conservation supervision institute strictly implemented national laws and regulations of soil and water conservation and contract requirements during the construction process. It implemented the management system and the corresponding measures of soil and water conservation. All indicators of soil and water conservation were conformity with the relevant requirements and standards.

\section{Investment Evaluation of Soil and Water Conservation}

Engineering practical investment on soil and water conservation was 48.87 million yuan, which increased by 32.91 million yuan, in compliance with the approved plan of soil and water conservation investment of 15.96 million yuan. The major change was that the engineering measures and vegetation measures investment increased, which the engineering measures invested 19.34 million yuan, increased 15.38 million yuan over the plan approval. This was because the column added to the evaluation of the slurry masonry sash slope protection, precast block revetment, the three dimensional net road slope protection and slope protection engineering and riverbanks ditch, prefabricated drains, concrete cover plate of ditches to drain engineering such as soil and water conservation investment. The plant investment was 25.28 million yuan, increased 18.96 million yuan over the plan approval, this was due to the construction unit attached great importance to the greening, implemented a comprehensive deserts greening measures on both sides of highway. Temporary measures investment was 0.42 million yuan, the plan approval dropped by 0.07 million yuan. The soil and water conservation investment was reasonable.

\section{Effect Evaluation of Soil and Water Conservation}

Disturbance in the surface area of the project was $10.71 \mathrm{hm} 2$; the completed management of soil and water conservation area was $87.74 \mathrm{hm} 2$, hardening of the surface and permanent buildings area was $122.14 \mathrm{hm} 2$, the actual vegetation covers area of project completed was $81.19 \mathrm{hm} 2$, the average annual soil erosion modulus of design level was $376 \mathrm{t} /(\mathrm{km} 2$.a). The disturbed land reclamation rate 
was $99.13 \%$, the total soil erosion degree was $98.64 \%$, block slag rate was $99.74 \%$, the vegetation of recovery rate was $99.41 \%$, grass coverage rate of $38.53 \%$ by calculated, which were in compliance with the approved plan of the target.

\section{The Situation Improved by Assessment}

The construction unit shall supervised construction units to assess the issues raised by the corrective perfect item by item in accordance with the technical assessment requirements. It also compiled the water and soil conservation facilities completion data. Project site after rectification measures were carried out the verification case as shown in figure 1 to figure 3 .
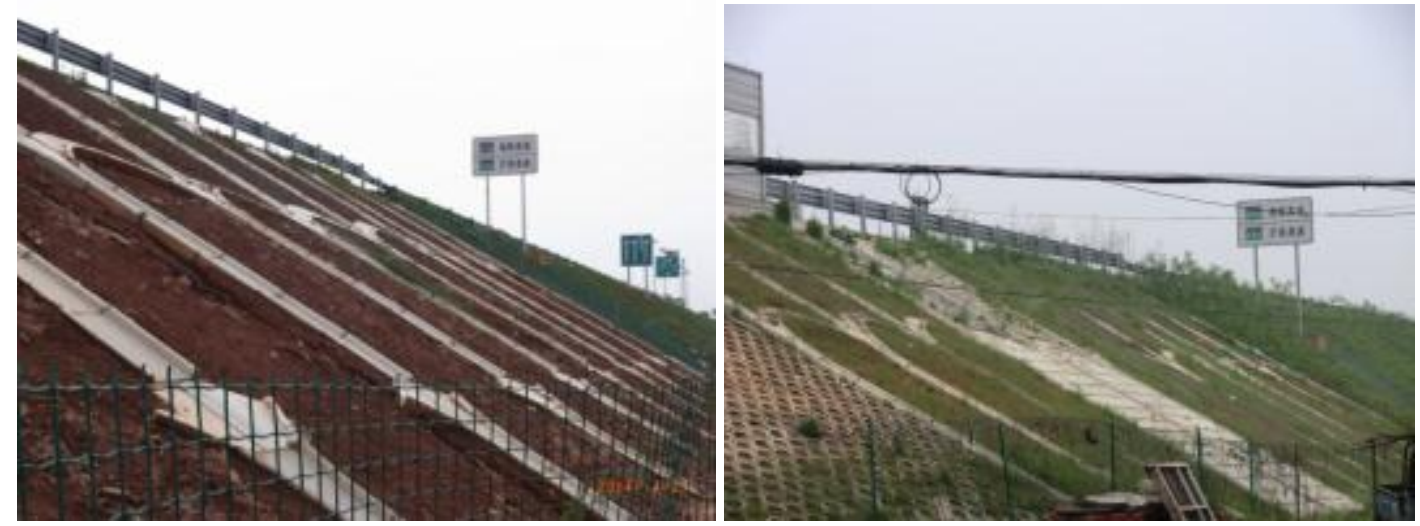

Fig.1 Slope of subgrade engineering area before (left) and after (right) the rectification
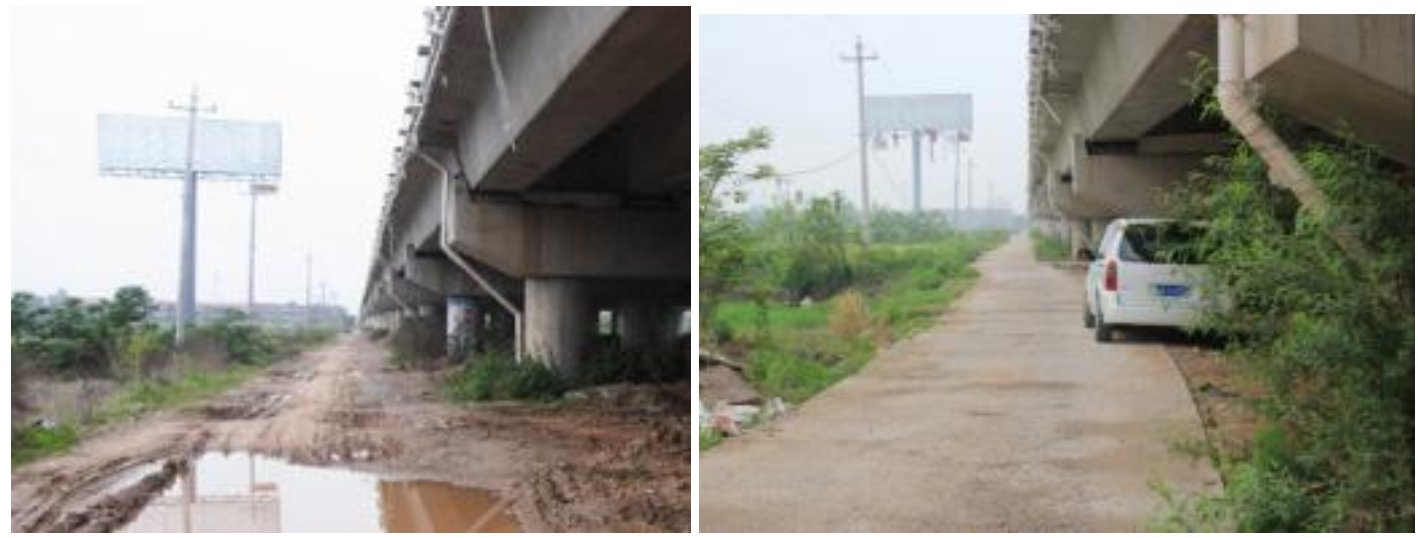

Fig.2 Construction road section before (left) and after (right) the rectification
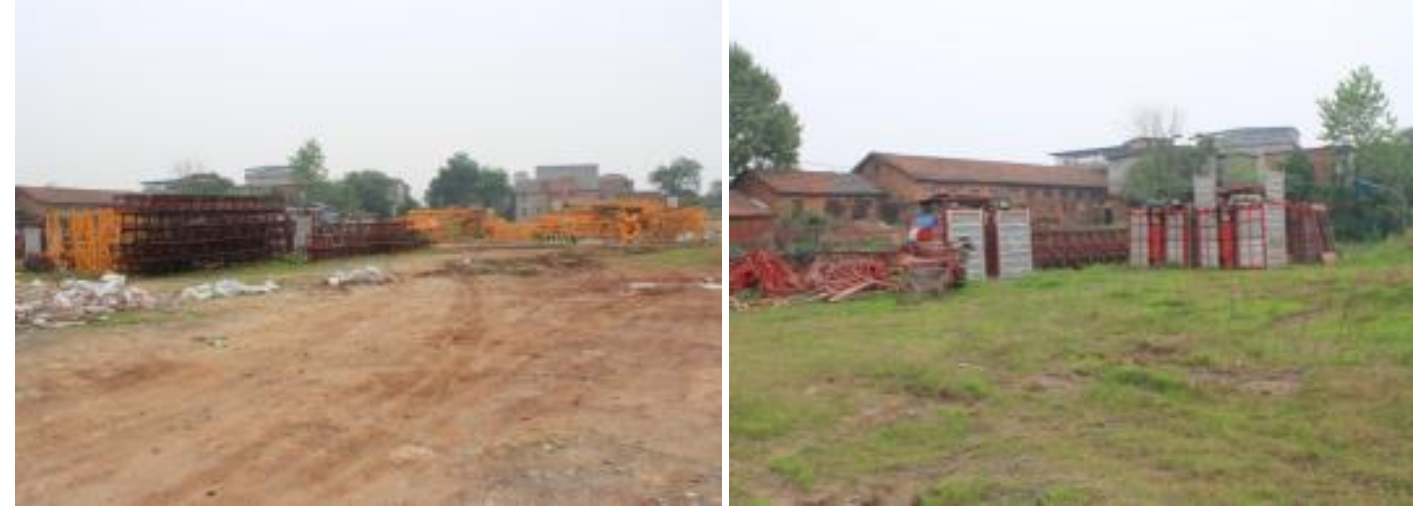

Fig.3 Abandon slag field area before (left) and after (right) the rectification 


\section{Conclusion and Experience}

The soil and water conservation program of this project was completed, the comprehensive inspection was qualified, The soil and water conservation measures were gotten the building. The six indicators were marked. Investment and financial management systems were reasonable. Construction management system was perfect in the late. Water and soil conservation facilities of Jiujiang Changjiang river highway bridge of Fuzhou to Yinchuan expressway werd implemented. The quality was overall, which achieved the target of prevention and control of soil erosion. The project met the condition of the completion acceptance.

At present, the project has passed the ministry of water resources water and soil conservation facilities completion inspection and acceptance, officially put into operation. Highway water and soil conservation facilities acceptance check should focus on the outside of main line temporary works such as earth, abandon slag field, construction production living area of soil and water conservation measures to carry out the situation. To be justified and objective truth, we should refer to soil and water conservation engineering documents, Compare with the situation of the soil and water conservation scheme design one by one. Through the study of the project there was a certain guiding significance to carry out highway facilities acceptance of soil and water conservation in the future.

\section{Acknowledgement}

This research was financially supported by the Basic Science Foundation "Leaf dark respiration and its inhibitory under the light response to the nitrogen addition and soil moisture (CKSF2016007/TB) ".

\section{References}

[1] Chen Shengjun. Practiceof acceptance evaluation of soil and water conservation facilities on Lingchuan to Santang high speedway, J. China Water and Soil Conservation, 2012(3):63-34.

[2] Ni Bing, Tian Hongwei, Yang Lei, etc.Assessment of Ecosystem Service Value On Biological Practice for Soil and Water Conservation for Highway--A Case Study of Three Highways in Different Regions of Shaanxi Province, J. Arid Environmental Monitoring, 2014,28(1):31-35.

[3] Niu Lanlan. Water and soil conservation facilities acceptance technology assessment for highway construction projects - the national highway 110 ( from Changping Deshengkou to Yanqing Xiaying) reconstruction project as an example, J. Journal of water conservancy planning and design, 2015 (8) :14-15.

[4] Chen Zhisong, Exploration on the Technical Assessment of Soil and Water ConservationFacilities Check Before Acceptance, J. Journal of Guangdong Technical College of Water Resources and Electric Engineering, 2012,10 (1): 28-31.

[5] Zhang Xirong, GaoZhaoliang, Liu Aixia. The Problems and Suggestions of Technical Assessment in the Completion-based Check and Acceptance of Soil and Water ConservancyFacilities in China, J.Journal of Anhui AgriSci, 2010,38 (29): :16436-16440. 